\title{
KIAA1109 gene mutation in surviving patients with Alkuraya-Kučinskas syndrome: a review of literature
}

\author{
Kishore Kumar ${ }^{1}$, Anikha Bellad ${ }^{1,2}$, Pramada Prasad $^{3}$, Satish Chandra Girimaji ${ }^{4 *}$ and Babylakshmi Muthusamy ${ }^{1,2^{*}}$ (D)
}

\begin{abstract}
Background: Alkuraya-Kučinskas syndrome is an autosomal recessive disorder characterized by brain abnormalities associated with cerebral parenchymal underdevelopment, arthrogryposis, club foot and global developmental delay. KIAA1109, a functionally uncharacterized gene is identified as the molecular cause for Alkuraya-Kučinskas syndrome. Most of the reported mutations in KIAA1109 gene result in premature termination of pregnancies or neonatal deaths while a few mutations have been reported in surviving patients with global developmental delay and intellectual disability. To our knowledge, only three surviving patients from two families have been reported with missense variants in KIAA1109. In this study, we describe four surviving patients from two related families (a multiplex family) with global developmental delay and mild to severe intellectual disability with no other systemic manifestations. There were no miscarriages or neonatal deaths reported in these families.

Methods: X-chromosome exome panel sequencing was carried out in one patient and whole exome sequencing was carried out on the remaining three affected individuals and the unaffected father of the index family. Data analysis was carried out followed by variant filtering and segregation analysis. Sanger sequencing was carried out to validate the segregation of mutation in all four affected siblings and unaffected parents from both families.

Results: A novel homozygous missense mutation in a conserved region of KIAA1109 protein was identified. Sanger sequencing confirmed the segregation of mutation in both families in an autosomal recessive fashion.

Conclusion: Our study is the second study reporting a KIAA1109 variant in surviving patients with Alkuraya-Kučinskas syndrome. Our study expands the spectrum of phenotypic features and mutations associated with Alkuraya-Kučinskas syndrome.
\end{abstract}

Keywords: Neonatal death, Premature termination of pregnancy, Prenatal diagnosis, KIAA clones, Mental retardation, Miscarriages, Developmental delay, Club foot, Arthrogryposis

\footnotetext{
* Correspondence: girimaji@nimhans.ac.in; babylakshmi@ibioinformatics.org

${ }^{4}$ Department of Child and Adolescent Psychiatry, NIMHANS, Hosur Road, Bangalore 560029, India

'Institute of Bioinformatics, International Technology Park, Bangalore 560066, India

Full list of author information is available at the end of the article
}

(c) The Author(s). 2020 Open Access This article is licensed under a Creative Commons Attribution 4.0 International License, which permits use, sharing, adaptation, distribution and reproduction in any medium or format, as long as you give appropriate credit to the original author(s) and the source, provide a link to the Creative Commons licence, and indicate if changes were made. The images or other third party material in this article are included in the article's Creative Commons licence, unless indicated otherwise in a credit line to the material. If material is not included in the article's Creative Commons licence and your intended use is not permitted by statutory regulation or exceeds the permitted use, you will need to obtain permission directly from the copyright holder. To view a copy of this licence, visit http://creativecommons.org/licenses/by/4.0/ The Creative Commons Public Domain Dedication waiver (http://creativecommons.org/publicdomain/zero/1.0/) applies to the data made available in this article, unless otherwise stated in a credit line to the data. 


\section{Background}

Alkuraya-Kučinskas syndrome (MIM: 617822) is an autosomal recessive disorder characterized by severe brain malformations, arthrogryposis and club foot. The brain abnormalities include cerebral parenchymal underdevelopment, lissencephaly, ventriculomegaly, reduced white matter volume, corpus callosum agenesis, dysplasia of cerebellum, hypoplasia of the pons and brainstem dysgenesis. Besides, abnormalities in multiple organ systems such as cardiac, renal and ophthalmologic were reported [1]. Loss of function mutations in KIAA1109 have been reported as the cause for premature termination of pregnancies and perinatal deaths while some missense mutations were reported in surviving patients with global developmental delay and learning disabilities. The clinical features of the surviving patients with KIAA1109 mutations are distinct as compared to the features observed in fetuses/ new-borns carrying KIAA1109 mutations that causes miscarriages and perinatal deaths. Surviving patients with KIAA1109 mutations exhibited global developmental delay, mild to moderate learning disability, no development of speech, inability to stand or walk without support, muscle hypotonia, atrophy, stereotypic movements, dysmorphic features and early-onset epilepsy [1]. Behaviorally, the surviving patients exhibited poor concentration, self injuring behavior such as head-banging to express anger or frustration. Thus far, three surviving patients from two families have been reported with compound heterozygous missense variants [1].

In addition to Alkuraya-Kučinskas syndrome, KIAA1109 has been reported as a significantly associated molecule in several autoimmune disorders including moderate to severe asthma [2], ulcerative colitis and celiac disease [3-5], rheumatoid arthritis [6], psoriatic arthritis [7], type 1 diabetes [8], anterior uveitis [9] and allergic sensitization [10]. It has also been identified to be associated with prostate cancer [11] and endometrial cancer [12].

In order to understand and characterize previously unidentified genes of larger size (>50 KDa) in brain, Ohara et al and Kikuno et al cloned and sequenced 2031 cDNA clones from human brain library that includes 27 clones from fetal brain $[13,14]$. The sequences of these genes are made publicly available in a repository known as $\mathrm{Hu}-$ man Unidentified Gene-Encoded (HUGE) (http://www. kazusa.or.jp/huge/). As part of this project, KIAA1109 gene was first sequenced from an adult human brain library that encodes a large protein product of 5005 amino acids. The GRCh38 annotation of KIAA1109 gene in RefSeq lists one transcript (NM_015312.3) with experimental evidence and displays several other predicted transcripts including several non-protein coding transcripts of unknown significance [14]. KIAA1109 is abundantly expressed in human ovary followed by the amygdala, cerebellum, subthalamic nucleus, thalamus and spinal cord with moderate to low expression in the hippocampus, caudate nucleus, corpus callosum, substantia nigra, fetal liver and fetal brain [14]. Low expression in fetal brain was detected at protein level as shown in the Human Proteome Map [15] (https://www.humanproteomemap.org/protein.php?hpm_id=84162). The GTEx portal shows ubiquitous expression of KIAA1109 gene in 53 tissues that includes 13 different brain tissues (https://www.gtexportal.org/home/gene/KIAA1109).

KIAA1109 gene was discovered two decades ago, however, it remains uncharacterized. However, the published studies on this gene support its possible role in embryonic development [16] and the regulation of phagocytosis [17]. Tweek, the Drosophila ortholog of KIAA1109 is involved in regulating synaptic vesicle recycling [18], thus suggesting its role in brain related functions.

In this study, we report four individuals from two related Indian families affected with intellectual disability and global developmental delay. Exome sequencing revealed a novel potentially pathogenic mutation in KIAA1109 gene that well segregated in multiple members tested in this family. While several studies reported mutations in KIAA1109 in fetal demises and neonatal deaths, this is the second study reporting a novel KIAA1109 mutation in surviving patients with intellectual disability.

\section{Methods}

In this study, we aimed at identifying the genetic cause of intellectual disability in four patients from two related families. Blood samples were collected from the parents and affected individuals. To identify the potentially pathogenic variants, we first carried out G-banded karyotyping in two patients, chromosome microarray analysis in two patients and exome sequencing in affected and unaffected members in the families. Sanger sequencing was performed to confirm the segregation of the potentially pathogenic variant identified in the family.

\section{Blood sample collection and karyotyping}

Blood samples were collected from three affected male siblings from the index family and an affected male maternal cousin and the parents from both families. DNA isolation was carried out using QIAamp DNA minikit (Qiagen) as per the instrunctions given in the manufacturer's protocol. G-banded karyotyping was first carried out on two affected individuals (F1.III-2 and F2.III-2) representing one patient in each family, as described previously [19].

\section{Chromosome microarray analysis}

In order to identify larger genomic alterations, chromosomal microarray (CMA) analysis was performed on two 
patients (F1.IV-1 and F2.IV-2) representing one patient in each family, using a CytoScanTM $750 \mathrm{~K}$ array (Affymetrix, CA, USA). This microarray contains a comprehensive list of oligonucleotide probes $(750 \mathrm{~K})$ including a unique set of non-polymorphic probes $(550 \mathrm{~K})$ and a collection of bi-allelic single nucleotide polymorphism (SNP) probes $(200 \mathrm{~K})$ that enables genome wide screening of the variants. Analysis was carried out according to manufacturer's protocol. Approximately, $250 \mathrm{ng}$ of genomic DNA isolated from each of two affected individuals was digested with a restriction enzyme Nsp1. The digested fragments were then ligated with adapter sequences. These fragments were then PCR amplified using a single pair of primers that recognize the adapter sequences. Titanium Taq amplified PCR products of size $120 \mathrm{bp}$ to $2000 \mathrm{bp}$ were purified using AMP pure beads and fragmented to a range of product size of $25 \mathrm{bp}$ to $125 \mathrm{bp}$. Subsequently, the fragmented PCR products were end labelled with biotin and the amplified and size selected products were then hybridized on CytoScan $750 \mathrm{~K}$ gene chip, and then scanned. Data analysis was performed using Chromosome Analysis Suite v1.2 (ChAS) (Affymetrix Inc., USA) based on human reference genome (GRCh37/hg19) using default parameters. The quality filtered raw data is subjected to CNV analysis. To identify the genes in CNVs and to evaluate the pathogenicity of the identified CNVs, we queried the following databases: i) Database of Genomic Variants (DGV) (http://dgv.tcag.ca/dgv/app/home), ii) DECIPHER (https://decipher.sanger.ac.uk/), iii) UCSC Genome browser (http://genome.ucsc.edu/) and iv) PubMed (http://www.ncbi.nlm.nih.gov/pubmed). In addition to the $\mathrm{CNV}$ analysis, loss of heterozygosity (LOH) analysis was also carried out using ChAS software.

\section{Exome sequencing}

In order to identify single nucleotide variants and small insertions and deletions, we carried out exome sequencing on all affected indidivudals and an unaffected father (II-2). X-chromosome exome panel (X-panel) sequencing was carried out on the index patient and whole exome sequencing was carried out on the remaining three patients and unaffected father of index family. X-panel and whole exome sequencing and data analysis were carried out as described previously [19]. Briefly, paired end sequencing $(2 \times 150)$ reads were generated with a target depth of coverage of 100x. Quality filtered raw reads were aligned to the human reference genome (hg19) and post alignment quality recalibrated reads were subjected to joint variant calling across all five datasets. Variants were annotated using ANNOVAR [20] and rare variants with minor allele frequency $<0.01$ were retained after comparing the variants with variants in 1000 genomes project [21], Exome Aggregation Consortium (ExAC)
[22] and gnomAD (https://www.biorxiv.org/content/1 $0.1101 / 531210 v 2)$. Subsequently, potential pathogenecity of the identified variants were evaluated using the publicly available tools such as SIFT [23], Polyphen-2 [24], MutationTaster-2 [25] and CADD [26]. Further, autosomal recessive variants, compound heterozygous variants and X-linked recessive variants were identified from filtered variants data. Compound heterozygous variants were identified using the following filtering steps: i) heterozygous variants in unaffected father and the same heterozygous variants in the patients, ii) a different heterozygous variant in the same gene found in patients but not present in the father which could have either been inherited from the mother or occurred as de novo mutations and iii) the potentially pathogenic nature of variants were interpreted manually.

\section{Sanger sequencing}

Sanger sequencing was performed on the potentially pathogenic KIAA1109 gene variant using the following procedure: Sanger confirmation was done on the index family (three affected siblings and their parents) and their cousin's family (one affected individual and his parents). Primer Quest Tool (http://eu.idtdna.com/Primerquest/ Home/Index) was used to design the primers $\left(5^{\prime}\right.$ TGCCAAGCAGCTATGTGTAAG-3' and 5'-ATGTAA AGTCCTTGAACACCCA-3') to amplify a 726 bp region of KIAA1109. OneTaq 2X Master Mix was used as per the manufacturer's protocol. The DNA molecules were denatured at $95^{\circ} \mathrm{C}$ for $30 \mathrm{~s}$, followed by 35 cycles of denaturation at $95^{\circ} \mathrm{C}$ for $30 \mathrm{~s}$. The primers annealing temperature was set to $60^{\circ} \mathrm{C}$ for $30 \mathrm{~s}$ and extended for $45 \mathrm{~s}$ at $68^{\circ} \mathrm{C}$. The final extension was at $68^{\circ}$ for $5 \mathrm{~min}$. The PCR products were cleaned and Sanger sequencing was carried out. The sequences obtained from sequencing were aligned to the reference genome to look for the mutations using BLAST tool. The chromatograms were analyzed manually to visualize the KIAA1109 mutation to study its segregation in the patients and obligate carrier parents from both families.

\section{Results}

\section{Patients}

The family described here is a multiplex family from the state of Karnataka in India. The multiplex family comprises four adult males affected with intellectual disability and global developmental delay. Two male siblings (F1.II-2 and F2.II-3) in this multiplex family had consanguineous marriages with the daughters (F1.III-1 and F2.III-4) of one of their sisters (II-4). The index family (F1) comprises three affected male siblings (F1.IV-1, F1.IV-2 and F1.IV-3). The second family (F2) comprises one affected male (F2.IV-2) and two unaffected females (Fig. 1a). The degree of intellectual disability varies 


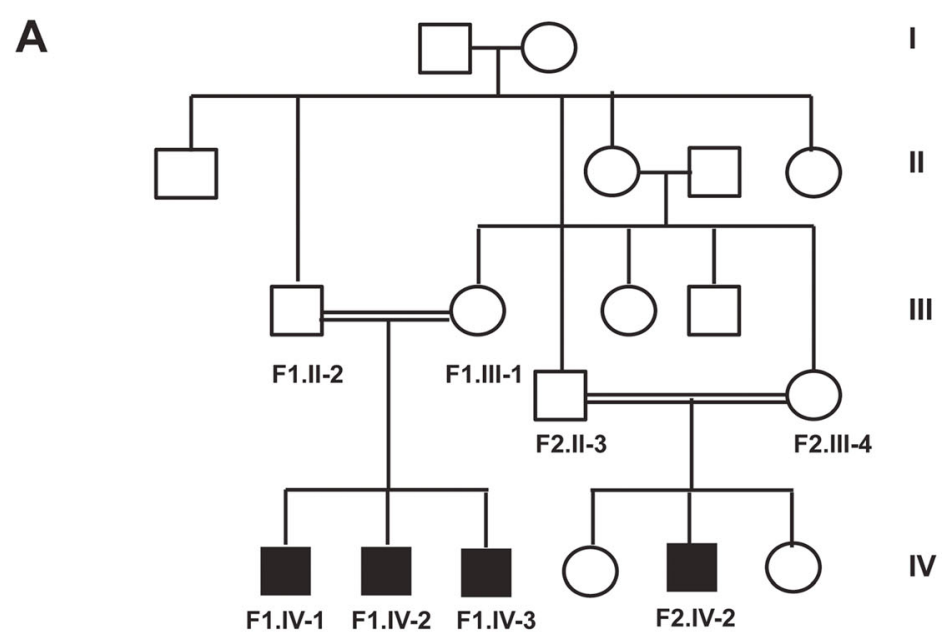

B


F2.IV-2
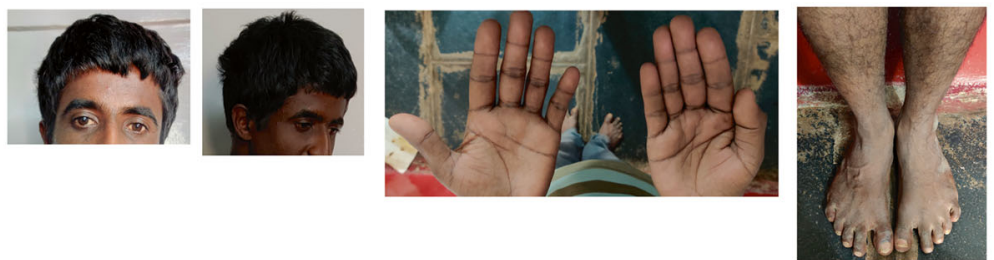

F1.IV-2

Fig. 1 Pedigree and clinical photographs. a Pedigree depicting affected and unaffected individuals and consanguinity, b Clinical photographs describing dysmorphic features, simian crease and low muscle mass in legs of patient F2.IV-2 and F1.IV-2

among the affected siblings. The parents and the females in both families are phenotypically normal. The clinical photographs describing the phenotypic features of patients F1.IV-2 and F2.IV-2 representing each family is depicted in Fig. 1b.

All four boys were born by uncomplicated vaginal delivery following uneventful gestation. Patients F2.IV-2 and F1.IV-3 displayed delays in gross motor milestones with the former learning to walk independently only by 3 years, and the latter by about 18 months. These two patients also had delayed language milestones, learning to say two words by only about 5 and 7 years, respectively.

The four boys were brought to medical attention at the same time after the parents noticed F1.IV-1 underperform at school. They were brought to our clinic about 10 years ago when their ages were 28 (F1.IV-1), 21
(F1.IV-2), 14 (F2.IV-2), and 13 (F1.IV-3). They were diagnosed with intellectual disability (ID) of varying severity, with F2.IV-2 recording the lowest IQ of 29 as a case of severe ID. While F1.IV-3 was diagnosed with mild to moderate ID, it was also noted that he showed signs of social anxiety. F1-IV-1 was noted to show some dysmorphic features including a high arched palate with low set ears. None of the patients suffers from any other systemic illness.

Patients F1.IV-2 and F2.IV-2 were re-examined recently, however, the other two siblings declined to be assessed. F2.IV-2 at 24 years of age continues to have severe ID, with his speech restricted to phrases and short sentences. While he can read the clock and sign his name, he is unable to count beyond ten. His parents reported that he could care for himself, but being shy and asocial, he did not help with any outdoor errands. He 
also had a history of being impulsive and irritable with occasional headbanging. Though bashful during the examination he smiled when making eye contact. $\mathrm{He}$ had a lanky appearance with an elongated face, his arm span matching his height. His oral cavity showed a higharched palate and protruding teeth on large gums. He had cubitus valgus and a palmar simian crease (right hand). Neurological examination revealed decreased muscle mass but was otherwise unremarkable. The rest of the systemic examination did not reveal anything significant.

At 31 years of age, F1.IV-2 is also intellectually disabled, though to a milder degree and he was more cooperative and amenable to being examined. He spoke

Table 1 Clinical phenotypic features of all four patients

\begin{tabular}{|c|c|c|c|c|}
\hline & F1.IV-1 & F1.IV-2 & F1.IV-3 & F2.IV-2 \\
\hline Age & 38 & 31 & 23 & 24 \\
\hline $\begin{array}{l}\text { Miscarriages/ } \\
\text { neonatal deaths }\end{array}$ & Nil & Nil & Nil & $\mathrm{Nil}$ \\
\hline Labour & FTND & FTND & FTND & FTND \\
\hline $\begin{array}{l}\text { Delayed } \\
\text { Milestones - } \\
\text { general }\end{array}$ & Yes & Yes - mild & Yes - mild & Gross delay \\
\hline $\begin{array}{l}\text { Walking } \\
\text { independent }\end{array}$ & 1.5 years & 1.5 years & 1.5 years & 3 years \\
\hline $\begin{array}{l}\text { Speaking two } \\
\text { meaningful } \\
\text { words }\end{array}$ & 1.5 years & 1.5 years & $6-7$ years & $4-5$ years \\
\hline $\begin{array}{l}\text { Other salient } \\
\text { historical points }\end{array}$ & NS & NS & NS & $\begin{array}{l}\text { Brain imaging done } \sim 5 \text { y back, reportedly abnormal, } \\
\text { records not available }\end{array}$ \\
\hline ID severity & Mild & Mild & $\begin{array}{l}\text { Moderate with } \\
\text { expressive } \\
\text { speech delay }\end{array}$ & severe \\
\hline IQ & ND & 57 & 43 & 29 \\
\hline Behavior & Shy, uncooperative & $\begin{array}{l}\text { Cooperative, } \\
\text { self-care fair }\end{array}$ & Social anxiety & $\begin{array}{l}\text { Impulsive, irritable, short tempered, stubborn, occasional } \\
\text { head-banging, shy/asocial }\end{array}$ \\
\hline Height/cm & 163 & 161 & $\begin{array}{l}\text { Could not be } \\
\text { measured }\end{array}$ & $\begin{array}{l}164 \\
\text { Arm-span (164) }\end{array}$ \\
\hline $\begin{array}{l}\text { Head } \\
\text { Circumference/ } \\
\text { cm }\end{array}$ & 54 & 55 & 42 & 55.5 \\
\hline $\begin{array}{l}\text { Chest } \\
\text { Circumference/ } \\
\text { cm }\end{array}$ & Could not be measured & 82 & $\begin{array}{l}\text { Could not be } \\
\text { measured }\end{array}$ & 72 \\
\hline $\begin{array}{l}\text { Mid-arm } \\
\text { Circumference/ } \\
\text { cm }\end{array}$ & Could not be measured & 24 & $\begin{array}{l}\text { Could not be } \\
\text { measured }\end{array}$ & 18 \\
\hline Vitals & Could not be measured & $\begin{array}{l}\text { BP } 124 / 80 \\
\mathrm{mmHg}\end{array}$ & $\begin{array}{l}\text { Could not be } \\
\text { measured }\end{array}$ & BP $100 / 60 \mathrm{mmHg}$ \\
\hline $\begin{array}{l}\text { Major } \\
\text { Congenital } \\
\text { Anomalies }\end{array}$ & Nil & Nil & Nil & $\mathrm{Nil}$ \\
\hline $\begin{array}{l}\text { Minor } \\
\text { Congenital } \\
\text { Anomalies }\end{array}$ & $\begin{array}{l}\text { High arched palate, low set ears, } \\
\text { prominent eyebrows, curly hair, } \\
\text { mild beaking of the nose }\end{array}$ & $\begin{array}{l}\text { High arched } \\
\text { palate }\end{array}$ & $\begin{array}{l}\text { Could not be } \\
\text { examined }\end{array}$ & $\begin{array}{l}\text { Malformed dentition, high arched palate, pointed ear on } \\
\text { rt. side, long face, simian crease rt. hand, long thumb, } \\
\text { small sub-mental region, cubitus valgus, high-arched foot }\end{array}$ \\
\hline $\begin{array}{l}\text { External } \\
\text { genitalia }\end{array}$ & Normal & $\begin{array}{l}\text { Could not be } \\
\text { examined }\end{array}$ & $\begin{array}{l}\text { Could not be } \\
\text { examined }\end{array}$ & normal \\
\hline $\begin{array}{l}\text { Neurological } \\
\text { Examination, } \\
\text { salient findings }\end{array}$ & No apparent abnormalities & $\begin{array}{l}\text { No apparent } \\
\text { abnormalities }\end{array}$ & $\begin{array}{l}\text { No apparent } \\
\text { abnormalities }\end{array}$ & $\begin{array}{l}\text { Muscle bulk less, rest of the systemic examination. No } \\
\text { apparent abnormalities }\end{array}$ \\
\hline
\end{tabular}

Patients F1.IV-2 and F2.IV-2 were examined on 20 Dec 2019. The physical examination findings of the other two patients are from the archives. None of the patients has a history of seizures or other systemic illnesses. NS Nothing significant, ND Not done 
Table 2 Mutations and phenotypic features of surviving patients with KIAA1109 mutations

\begin{tabular}{|c|c|c|c|c|c|c|c|}
\hline Reference & $\begin{array}{l}\text { This study, } \\
\text { F1.IV-1 }\end{array}$ & $\begin{array}{l}\text { This study, } \\
\text { F1.IV-2 }\end{array}$ & $\begin{array}{l}\text { This study, } \\
\text { F1.IV-3 }\end{array}$ & This study, F2.IV-2 & $\begin{array}{l}\text { Gueneau, et al., } \\
2018 \text { [1] }\end{array}$ & $\begin{array}{l}\text { Gueneau, et al., } \\
2018 \text { [1] }\end{array}$ & $\begin{array}{l}\text { Gueneau, et al., } \\
2018 \text { [1] }\end{array}$ \\
\hline Sex, Age & Male, 38 yo & Male, 31 yo & Male, 23 yo & Male, 24 yo & Male, 13 yo & Female, 7 yo & Female, 11 yo \\
\hline Mutation & $\begin{array}{l}\text { g. } \\
123140678 A> \\
\text { G; c.2431A > G } \\
\text { (hom) }\end{array}$ & $\begin{array}{l}\text { g. } \\
\text { 123140678A > } \\
\text { G; C.2431A > G } \\
\text { (hom) }\end{array}$ & $\begin{array}{l}\text { g. } \\
\text { 123140678A > } \\
\text { G; c.2431A > G } \\
\text { (hom) }\end{array}$ & $\begin{array}{l}\text { g. } 123140678 A> \\
\text { G; c. } 2431 A>G \\
\text { (hom) }\end{array}$ & $\begin{array}{l}\text { Chr4:123160823; } \\
\text { c.3986A > C (het) } \\
\text { Chr4:123170727; } \\
\text { c.5599G > A (het) }\end{array}$ & $\begin{array}{l}\text { Chr4:123160823; } \\
\text { c.3986A > C } \\
\text { (het) } \\
{ }^{a} \text { Chr4: } \\
\text { 123170727; } \\
\text { c.5599G > A } \\
\text { (het) }\end{array}$ & $\begin{array}{l}\text { Chr4:123164200; } \\
\text { c.4719G > A (het) } \\
\text { and Chr4: } \\
\text { 123171679; } \\
\text { c.5873G > A (het) }\end{array}$ \\
\hline Protein Change & p.Thr811Ala & p.Thr811Ala & p.Thr811Ala & p.Thr811Ala & $\begin{array}{l}\text { p.Tyr1329Cys } \\
\text { and } \\
\text { p.Val1867Met }\end{array}$ & $\begin{array}{l}\text { p.Tyr1329Cys } \\
\text { and } \\
\text { p.Val1867Met }\end{array}$ & $\begin{array}{l}\text { p.Met1573lle and } \\
\text { p.Arg1958Gln }\end{array}$ \\
\hline ID & Mild & Mild & Moderate & Severe & Severe & Severe & Moderate \\
\hline Neuropsychiatric & $\begin{array}{l}\text { Delayed } \\
\text { motor } \\
\text { milestones, } \\
\text { shy and } \\
\text { uncooperative }\end{array}$ & $\begin{array}{l}\text { Delayed } \\
\text { motor } \\
\text { milestones }\end{array}$ & $\begin{array}{l}\text { Expressive } \\
\text { speech delay, } \\
\text { delayed } \\
\text { motor } \\
\text { milestones, } \\
\text { social anxiety }\end{array}$ & $\begin{array}{l}\text { Delayed motor } \\
\text { and language } \\
\text { milestones, } \\
\text { impulsive, irritable, } \\
\text { short-tempered, } \\
\text { stubborn, occa- } \\
\text { sional head- } \\
\text { banging, shy/ } \\
\text { asocial }\end{array}$ & $\begin{array}{l}\text { Global } \\
\text { developmental } \\
\text { delay, no language, } \\
\text { cannot stand or } \\
\text { walk without } \\
\text { support, early } \\
\text { onset epilepsy }\end{array}$ & $\begin{array}{l}\text { Global } \\
\text { developmental } \\
\text { delay, no } \\
\text { language, } \\
\text { cannot sit or } \\
\text { stand without } \\
\text { support, } \\
\text { stereotypic } \\
\text { movements, } \\
\text { early onset } \\
\text { epilepsy }\end{array}$ & $\begin{array}{l}\text { Global } \\
\text { developmental } \\
\text { delay, mild to } \\
\text { moderate learning } \\
\text { disability, poor } \\
\text { concentration, } \\
\text { immature behavior } \\
\text { with minor self- } \\
\text { harm (head-bang- } \\
\text { ing) when angry/ } \\
\text { frustrated }\end{array}$ \\
\hline Imaging & Not done & Not done & Not done & Not available & $\begin{array}{l}\text { Post-natal brain } \\
\text { MRI: small posterior } \\
\text { fossa arachnoid } \\
\text { cyst, discrete } \\
\text { vermian atrophy, } \\
\text { slight increase in } \\
\text { the fluid-filled } \\
\text { retro- and infracer- } \\
\text { ebellar space and } \\
\text { mild enlargement } \\
\text { of subarachnoid } \\
\text { spaces of frontal } \\
\text { regions }\end{array}$ & $\begin{array}{l}\text { Post-natal brain } \\
\text { MRl: discrete } \\
\text { parenchymal } \\
\text { rarefaction } \\
\text { involving the } \\
\text { frontal lobes }\end{array}$ & $\begin{array}{l}\text { Prenatal imaging } \\
\text { (US and MRI): major } \\
\text { microcephaly (HC } \\
-5 \text { SD) with } \\
\text { reduced white } \\
\text { matter volume and } \\
\text { mild } \\
\text { ventriculomegaly }\end{array}$ \\
\hline Head and neck & $\begin{array}{l}\text { High arched } \\
\text { palate, low set } \\
\text { ears, } \\
\text { prominent } \\
\text { eyebrows, } \\
\text { mild beaking } \\
\text { of the nose }\end{array}$ & $\begin{array}{l}\text { High arched } \\
\text { palate }\end{array}$ & - & $\begin{array}{l}\text { Malformed } \\
\text { dentition, high } \\
\text { arched palate, } \\
\text { pointed ear on } \\
\text { right side, long } \\
\text { face, simian crease } \\
\text { right hand, long } \\
\text { thumb, small sub- } \\
\text { mental region }\end{array}$ & $\begin{array}{l}\text { Plagiocephaly, } \\
\text { refractive errors of } \\
\text { the eyes, delayed } \\
\text { dentition }\end{array}$ & $\begin{array}{l}\text { Plagiocephaly, } \\
\text { refractive errors } \\
\text { of the eye, } \\
\text { strabismus }\end{array}$ & $\begin{array}{l}\text { Hypertelorism, } \\
\text { slightly upslanting } \\
\text { palpebral fissures, } \\
\text { ocular motor } \\
\text { apraxia, refractive } \\
\text { errors of the eye, } \\
\text { strabismus, dental } \\
\text { crowding, high } \\
\text { palate }\end{array}$ \\
\hline Skeletal System & - & - & - & $\begin{array}{l}\text { Cubitus valgus, } \\
\text { high-arched foot, } \\
\text { reduced muscle } \\
\text { bulk }\end{array}$ & $\begin{array}{l}\text { Mild contractures } \\
\text { of large joints, } \\
\text { syndactyly of 2nd } \\
\text { and 3rd toes, limb } \\
\text { paresis at birth, } \\
\text { talipes valgus, } \\
\text { muscle hypotonia } \\
\text { and atrophy }\end{array}$ & $\begin{array}{l}\text { Mild } \\
\text { contractures of } \\
\text { large joints, } \\
\text { paretic position } \\
\text { of hands and } \\
\text { feet in infancy, } \\
\text { talipes valgus, } \\
\text { muscle } \\
\text { hypotonia and } \\
\text { atrophy }\end{array}$ & $\begin{array}{l}\text { Asymmetry of the } \\
\text { thorax, mild } \\
\text { bilateral talipes, } \\
\text { syndactyly of 2nd } \\
\text { and 3rd toes, 5th } \\
\text { toe clinodacytly, } \\
\text { hallux valgus }\end{array}$ \\
\hline GI & - & - & - & - & - & $\begin{array}{l}\text { Chronic } \\
\text { constipation }\end{array}$ & $\begin{array}{l}\text { Gastroesophageal } \\
\text { reflux }\end{array}$ \\
\hline Heart & - & - & - & - & - & - & $\begin{array}{l}\text { Tetralogy of Fallot } \\
\text { with pulmonary } \\
\text { atresia }\end{array}$ \\
\hline Urogenital & - & - & - & - & Scrotal hypoplasia & - & - \\
\hline
\end{tabular}


Table 2 Mutations and phenotypic features of surviving patients with KIAA1109 mutations (Continued)

\begin{tabular}{|c|c|c|c|c|c|c|c|}
\hline Reference & $\begin{array}{l}\text { This study, } \\
\text { F1.IV-1 }\end{array}$ & $\begin{array}{l}\text { This study, } \\
\text { F1.IV-2 }\end{array}$ & $\begin{array}{l}\text { This study, } \\
\text { F1.IV-3 }\end{array}$ & This study, F2.IV-2 & $\begin{array}{l}\text { Gueneau, et al., } \\
2018 \text { [1] }\end{array}$ & $\begin{array}{l}\text { Gueneau, et al., } \\
2018 \text { [1] }\end{array}$ & $\begin{array}{l}\text { Gueneau, et al., } \\
2018 \text { [1] }\end{array}$ \\
\hline Other & - & - & - & - & - & $\begin{array}{l}\text { Dermatitis, } \\
\text { psoriasis }\end{array}$ & - \\
\hline
\end{tabular}

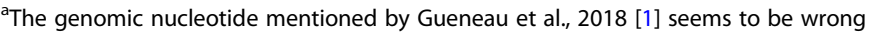

clearly and coherently in short sentences. He was gainfully employed in the family business of weaving. Physical examination revealed a high arched palate, but the rest of the examination was unremarkable.

Table 1 describes the clinical findings from all four patients. A detailed comparison of phenotypic features of previously reported surviving patients and the phenotypes observed in these patients along with the identified/reported mutations are provided in Table 2. Unlike previously reported patients with KIAA1109 mutations, there is no unexplained intrauterine fetal demise in these families. These patients did not have any overlapping features of patients reported previsouly with perinatal deaths.

\section{Karyotyping and chromosome microarray analysis}

In order to look for any chromosomal abnormalities, Gbanded karyotyping was carried out on two affected siblings F1.VI-2 and F2.IV-2 representing one patient in each family. The chromosomes were normal with 46, $\mathrm{XY}$ complement. Since the patients exhibited nonsyndromic phenotypes including developmental delay and intellectual disability, the diagnostic yield of Gbanded karyotyping is $\sim 3 \%$ and chromosome microarray analysis is often recommended as a first-tier diagnostics test [27]. CytoScan $750 \mathrm{~K}$ Array was used since it has a comprehensive list of probes with higher sensitivity and specificity to detect copy number variations in two affected individuals representing one in each family. Karyotypes were checked first which revealed normal chromosomes with 46, XY complement, consistent with G-banded karyotyping. CNV analysis was carried out using ChAS software and identified with $\mathrm{CNVs}$ and $\mathrm{LOH}$ regions. CNVs devoid of gene content or reported in general population were removed and the clinical relevance of the the identified $\mathrm{CNVs}$ were evaluated manually. The CNVs identified in both the patients were compared and we found that there is no potentially pathogenic CNVs addressing the phenotypes observed in the patients. Similarly, LOH analysis also did not yield any significant clinically relevant variants.

\section{Exome sequencing and identification of a novel mutation in KIAA1109}

Based on the inference from the pedigree, because only males are affected, we initially carried out X-panel sequencing of the index patient (F1.IV-1) expecting Xlinked recessive inheritance. Data analysis revealed no significant X-linked variants that fit the phenotypes observed in the patients. Whole exome sequencing was then carried out on the remaining patients (F1.IV-2, F1.IV-3 and F2.IV-2) and unaffected father (F1.II-2) of the index family (F1). Joint variant calling identified a total of 1,613,810 unfiltered variants. Exonic, and splice site variants were retained and common variants with minor allele frequency $<0.01$ were removed. A list of qualifying rare variants are provided in Supplementary Table 1. After applying autosomal recessive mode of inheritance pattern, a novel variant g.123140678A > G was identified that was found to be a homozygous in all three affected individuals (F1.IV-2, F1.IV-3 and F2.IV-2) and heterozygous in the unaffected father (F1.II-2). This variant is located at 4q27, a locus of autoimmune disorders [28]. This mutation was found in exon 19 of KIAA1109 gene (c.2431A > G) resulting in a missense variant altering threonine to alanine at position 811, p.Thr811Ala in KIAA1109 protein (RefSeq: NM_015312.3 (transcript) and NP_056127.2 (protein)) (Table 2). KIAA1109 encodes for a large protein that has no known functional domains or motifs. Although KIAA1109 gene is discovered two decades ago, it remains functionally uncharacterized. This variant is not reported in dbSNP, 1000 genomes project, ExAC and gnomAD databases. Polyphen-2 predicted the effect of p.Thr811Ala mutation as probably damaging (Score: 0.994 ), SIFT predicted the effect of the mutation as damaging (score: 0.05 ). MutationTaster predicted the effect of the mutation as disease-causing (score: 1 ).

In order to validate the KIAA1109 variant g.123140678A $>$ G and to study the segregation of mutation in the family, we carried out Sanger sequencing on the three affected individuals in the index family (F1.IV1, F1.IV-2, F1.IV-3), their parents (F1.II-3, F1.III-1), affected cousin (F2.IV-2) and his parents (F2.II-3, F2.III-4). The chromatograms of Sanger results confirmed the homozygous mutation in all affected patients and heterozygous mutation in all unaffected parents confirming the segregation of mutation in the family (Fig. 2a \& Fig. 2b). Conservation analysis of a region spanning p.Thr811Ala across species shows the conservation of the mutated residue and the residues around the site of the mutation (Fig. 3a). 


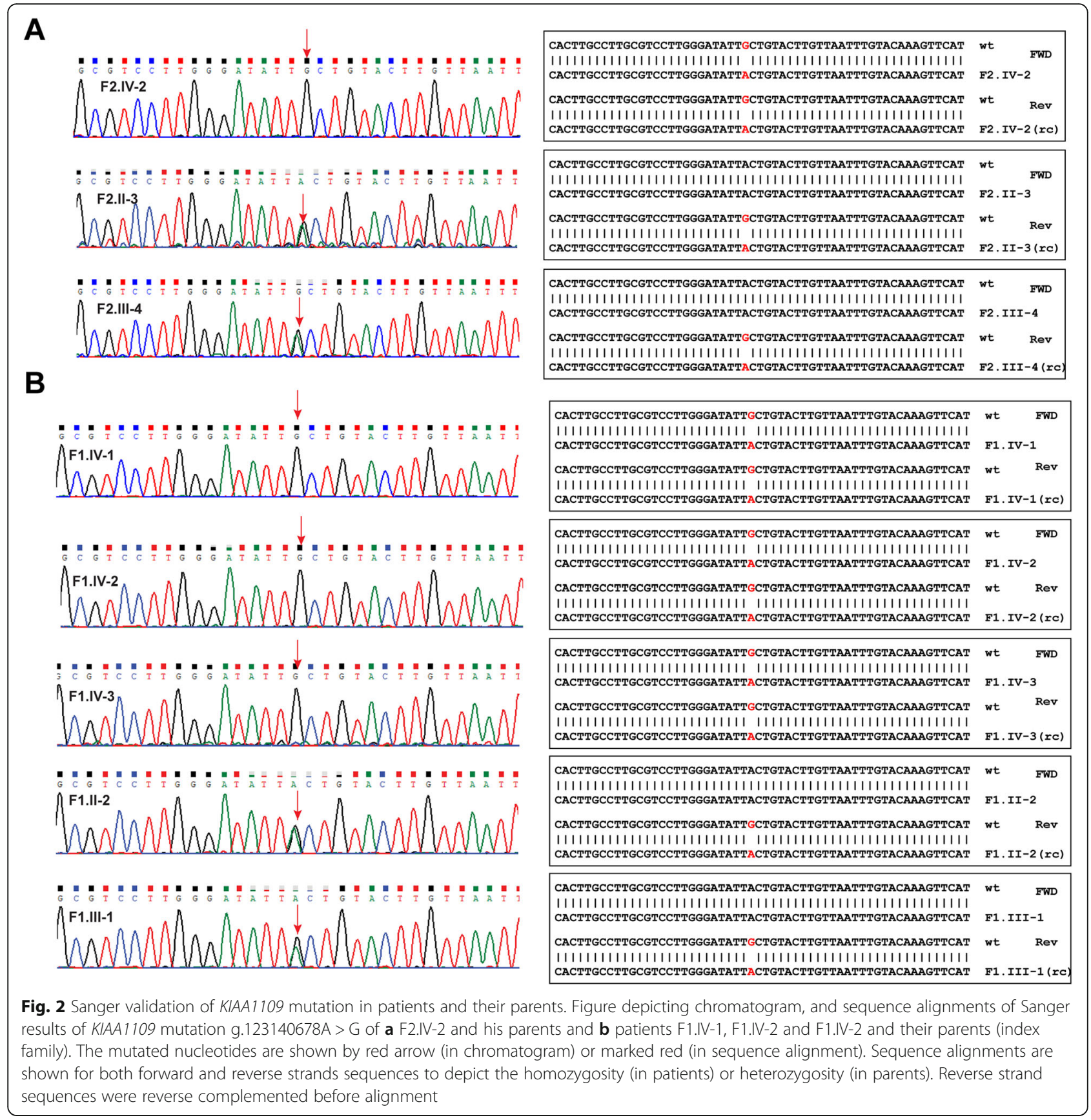

\section{Discussion}

KIAA1109 is a large and evolutionarily conserved protein with no known domains or motifs. A number of mutations in KIAA1109 have been reported in miscarriages and/or neonatal deaths and only one study has reported surviving patients with KIAA1109 mutations (Fig. 3b).

\section{KIAA1109 mutations causing miscarriages and neonatal deaths}

The association of KIAA1109 with neurogenetic disorders was first reported from a single family of a large cohort study of 143 consanguineous families comprising of two female patients (deceased) with Dandy-Walker malformation, hydrocephalus, flexed deformity, club feet, micrognathia, and pleural effusion [29]. Another study identified a large homozygous deletion spanning exons 28 to 55 in four neonatal deaths with patients exhibiting severe arthrogryposis and axillar pterygium [30]. The reason for death and age of death were not indicated. A subsequent study screening 44 families with terminating pregnancies identified two unrelated families with KIAA1109 mutations: i) a truncating mutation was 


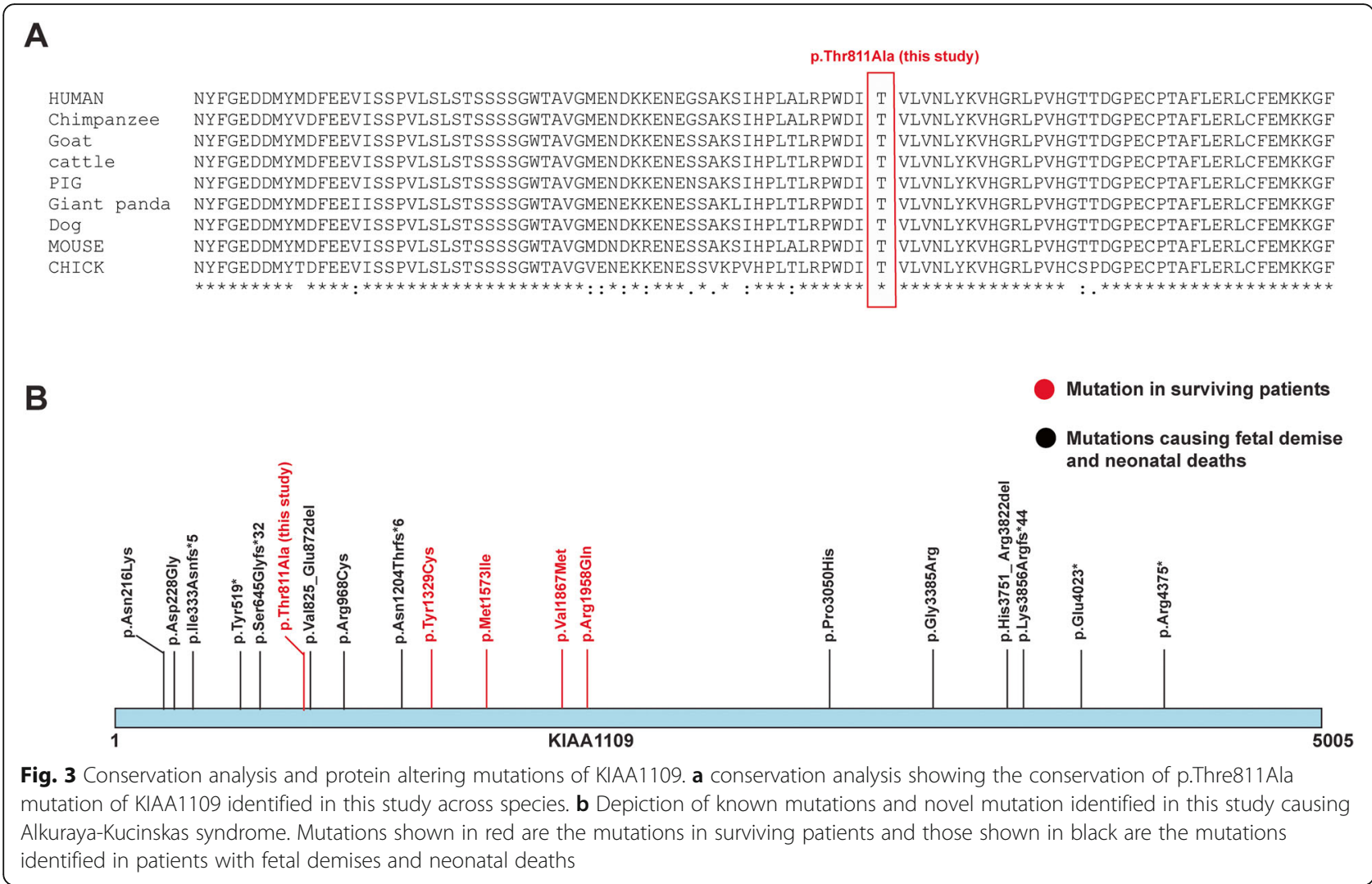

reported in a patient with hydrocephalus, hypoplastic cerebellum, skin edema and bilateral talipes with a history of two preceding intrauterine fetal deaths at 6 months of pregnancy with similar presentations (severe hydrocephalus, spina bifida, and polyhydramnios) and ii) a splice site mutation was identified in a patient with hydrocephalus and arthrogryposis [16]. Subsequently, the same group published 13 patients from 10 families with KIAA1109 mutations in fetuses with miscarriages and neonatal deaths. In addition to these, this study has reported three surviving patients with global developmental delay [1]. In a Russian family with a history of two miscarriages, two intronic compound heterozygous variants were identified both altering splicing leading to premature termination of the translation with a deletion of 46 amino acids of KIAA1109 protein [31]. These fetuses exhibited bilateral ventriculomegaly, arthrogryposis, bilateral pyelectasis, increased thickness of the nuchal fold and hypoplastic and low set ears and prenatal diagnosis aided in choosing the right pregnancy [31]. Subsequently, six patients with death during the neonatal period have been reported with similar overlapping phenotypes as described in previous patients with KIAA1109 mutations [32]. The growing literature on KIAA1109 mutations in premature termination of pregnancies demonstrates its possible role in development
[31]. These studies indicate that KIAA1109 plays a crucial role in fetal development. Although fetal malformations can be detected in utero using advanced imaging techniques, molecular diagnosis provides additional clues for a more accurate diagnosis.

\section{KIAA1109 mutations in surviving patients with intellectual disability and developmental delay}

Interestingly, only one previous study has reported missense mutations in KIAA1109 in surviving patients in a Lithuanian family with a male and a female children of ages 13 and 7 years, respectively exhibiting severe developmental delay and no speech (Table 2) [1]. Another British family with an 11 years old child exhibiting global developmental delay and mild to moderate learning disabilities has been reported (Table 2) [1]. We report here the third family with KIAA1109 mutation in surviving patients with global developmental delay and intellectual disability (Table 2). Unlike the other surviving cases reported, none of the patients in this study had major congenital anomalies or musculoskeletal involvement such as congenital heart disease, arthrogryposis, ocular manifestations or dysmorphic features. Thus, compared to surviving cases reported earlier, these patients had much milder phenotypes with varying degrees of ID as the 
predominant feature that expands the genotype and phenotype spectrum of Alkuraya-Kučinskas Syndrome.

\section{Conclusions}

Our description of the four surviving patients significantly expands the phenotypic features of AlkurayaKučinskas Syndrome. Our study is the second study to provide evidence for a role of KIAA1109 in intellectual disability in surviving patients. Identification of such mutations differentiating the mutations responsible for fetal demise and intellectual disability will greatly enhance the accuracy of prenatal diagnosis to aid informed decision making by prospective parents. A high degree of precision is essential for accurate genetic counseling and the pursuit of preventive options such as preimplantation and prenatal diagnosis. Molecular experiments to understand and differentiate the regions of KIAA1109 protein in manifesting these groups of disorders are warranted.

\section{Supplementary information}

Supplementary information accompanies this paper at https://doi.org/10. 1186/s12881-020-01074-2.

Additional file 1: Supplementary Table S1. List of qualitative rare variants identified from four patients and unaffected father of index family.

\section{Abbreviations}

MIM: Mendelian inheritance in man; cDNA: Complementary deoxyribonucleic acid; HUGE: Human unidentified gene-encoded; GRCh38: Genome reference consortium human build 38; BWA: Burrows-Wheeler aligner; PCR: Polymerase chain reaction; GVCF: Genomic variant call format; GATK: Genome analysis toolkit; ExAC: Exome aggregation consortium; gnomAD: Genome aggregation database; CADD: Combined annotation dependent depletion; CMA: Chromosome microarray; SNP: Single nucleotide polymorphism; ChAS: Chromosome analysis suite; CNV: Copy number variation; DGV: Database of genomic variants; LOH: Loss of heterozygosity; UCSC: University of california santa cruz; BLAST: Basic local alignment search tool; ID: Intellectual disability

\section{Acknowledgements}

The authors thank the families for participating in this study and for providing samples and written informed consent. We declare that the preprint of abstract of this manuscript is made available in Authorea website.

\section{Authors' contributions}

BM and SCG designed the study, revised and edited the manuscript. BM analyzed the data, interpreted the results and wrote the manuscript. KK and AB helped SCG for the clinical assessment of the patients, wrote clinical details and performed experiments. PP helped in experiments. All authors reviewed the manuscripts and gave inputs to improve the manuscript. The author(s) read and approved the final manuscript.

\section{Funding}

DBT-BioCARe scheme, Department of Biotechnology (DBT), Government of India (BT/PR18182/BIC/101/937/2016) provided funding to BM to carry out this study and provided research fellowship for BM.

\section{Availability of data and materials}

The datasets generated and analysed during the current study are made available as a supplementary table (Supplementary Table 1) that lists all qualified variants.

Human Proteome Map: https://www.humanproteomemap.org/protein. php?hpm_id=84162; GTEx portal: https://www.gtexportal.org/home/gene/
KIAA1109; Human genome GRCh37: https://ftp.ncbi.nlm.nih.gov/genomes/ all/GCF/000/001/405/GCF_000001405.39_GRCh38.p13/GCF_000001405.39_ GRCh38.p13_genomic.fna.gz; Population frequency annotation and functional effect prediction were annotated through ANNOVAR: https://doc-openbio.readthedocs.io/projects/annovar/en/latest/user-guide/ filter/

1000 genomes project, phase 3 ID: 1000g2015aug; ExAC ID: exac03; gnomAD exome ID: gnomad_exome; gnomAD genome ID: gnomad_genome; Scores of SIFT, Polyphen, MutationTaster and CADD from ANNOVAR ID: dbnsfp30a.

\section{Ethics approval and consent to participate}

This study was approved by the Ethics Committee at the National Institute of Mental Health and Neuro Sciences (NIMHANS), Bangalore. All the four patients in this study lacked mental capacity to consent. Due to this, we obtained written informed consent to participate in this study from the parents of both families.

\section{Consent for publication}

Written informed consents for publication of identifying images and the clinical details of the patients were obtained from the parents from both families as all four patients lacked mental capacity to consent.

\section{Competing interests}

The authors declare no competing interests.

\section{Author details}

${ }^{1}$ Institute of Bioinformatics, International Technology Park, Bangalore 560066, India. ${ }^{2}$ Manipal Academy of Higher Education, Manipal, Karnataka 576104, India. ${ }^{3}$ Department of Neurology, NIMHANS, Hosur Road, Bangalore 560029 , India. ${ }^{4}$ Department of Child and Adolescent Psychiatry, NIMHANS, Hosur Road, Bangalore 560029, India.

Received: 2 March 2020 Accepted: 19 June 2020

Published online: 26 June 2020

\section{References}

1. Gueneau L, Fish RJ, Shamseldin HE, Voisin N, Tran Mau-Them F, Preiksaitiene E, Monroe GR, Lai A, Putoux A, Allias F, et al. KIAA1109 variants are associated with a severe disorder of brain development and Arthrogryposis. Am J Hum Genet. 2018;102(1):116-32.

2. Shrine N, Portelli MA, John C, Soler Artigas M, Bennett N, Hall R, Lewis J, Henry AP, Billington CK, Ahmad A, et al. Moderate-to-severe asthma in individuals of European ancestry: a genome-wide association study. Lancet Respir Med. 2019;7(1):20-34.

3. Glas J, Stallhofer J, Ripke S, Wetzke M, Pfennig S, Klein W, Epplen JT, Griga T, Schiemann $U$, Lacher $M$, et al. Novel genetic risk markers for ulcerative colitis in the IL2/IL21 region are in epistasis with IL23R and suggest a common genetic background for ulcerative colitis and celiac disease. Am J Gastroenterol. 2009;104(7):1737-44.

4. Balasopoulou A, Stankovic B, Panagiotara A, Nikcevic G, Peters BA, John A, Mendrinou E, Stratopoulos A, Legaki Al, Stathakopoulou V, et al. Novel genetic risk variants for pediatric celiac disease. Hum Genomics. 2016;10(1):34.

5. Plaza-Izurieta L, Castellanos-Rubio A, Irastorza I, Fernandez-Jimenez N, Gutierrez G, Cegec BJR. Revisiting genome wide association studies (GWAS) in coeliac disease: replication study in Spanish population and expression analysis of candidate genes. J Med Genet. 2011;48(7):493-6.

6. Louahchi S, Allam I, Raaf N, Berkani L, Boucharef A, Abdessemed A, Khaldoun N, Bahaz N, Ladjouze-Rezig A, Nebbab A, et al. Association of rs6822844 within the KIAA1109/TENR/IL2/IL21 locus with rheumatoid arthritis in the Algerian population. HLA. 2016;87(3):160-4.

7. Schrodi SJ. Genome-wide association scan in psoriasis: new insights into chronic inflammatory disease. Expert Rev Clin Immunol. 2008;4(5):565-71.

8. Kiani AK, John P, Bhatti A, Zia A, Shahid G, Akhtar P, Wang X, Demirci FY, Kamboh Ml. Association of 32 type 1 diabetes risk loci in Pakistani patients. Diabetes Res Clin Pract. 2015;108(1):137-42.

9. Yang MM, Lai TY, Tam PO, Chiang SW, Chan CK, Luk FO, Ng TK, Pang CP. CFH $184 \mathrm{G}$ as a genetic risk marker for anterior uveitis in Chinese females. Mol Vis. 2011;17:2655-64.

10. Bonnelykke K, Matheson MC, Pers TH, Granell R, Strachan DP, Alves AC, Linneberg A, Curtin JA, Warrington NM, Standl M, et al. Meta-analysis of 
genome-wide association studies identifies ten loci influencing allergic sensitization. Nat Genet. 2013;45(8):902-6.

11. Tindall EA, Hoang HN, Southey MC, English DR, Hopper JL, Giles GG, Severi G, Hayes VM. The $4 \mathrm{q} 27$ locus and prostate cancer risk. BMC Cancer. 2010;10:69.

12. Qiao Z, Jiang Y, Wang L, Wang L, Jiang J, Zhang J. Mutations in KIAA1109, CACNA1C, BSN, AKAP13, CELSR2, and HELZ2 are associated with the prognosis in endometrial Cancer. Front Genet. 2019;10:909.

13. Ohara O, Nagase T, Ishikawa K, Nakajima D, Ohira M, Seki N, Nomura N. Construction and characterization of human brain CDNA libraries suitable for analysis of cDNA clones encoding relatively large proteins. DNA Res. 1997:4(1):53-9.

14. Kikuno R, Nagase T, Ishikawa K, Hirosawa M, Miyajima N, Tanaka A, Kotani H, Nomura N, Ohara O. Prediction of the coding sequences of unidentified human genes. XIV. The complete sequences of 100 new CDNA clones from brain which code for large proteins in vitro. DNA Res. 1999;6(3):197-205.

15. Kim MS, Pinto SM, Getnet D, Nirujogi RS, Manda SS, Chaerkady R, Madugundu AK, Kelkar DS, Isserlin R, Jain S, et al. A draft map of the human proteome. Nature. 2014;509(7502):575-81.

16. Shamseldin HE, Kurdi W, Almusafri F, Alnemer M, Alkaff A, Babay Z, Alhashem A, Tulbah M, Alsahan N, Khan R, et al. Molecular autopsy in maternal-fetal medicine. Genet Med. 2018;20(4):420-7.

17. Jeng EE, Bhadkamkar V, Ibe NU, Gause H, Jiang L, Chan J, Jian R, JimenezMorales D, Stevenson E, Krogan NJ, et al. Systematic identification of host cell regulators of legionella pneumophila pathogenesis using a genomewide CRISPR screen. Cell Host Microbe. 2019;26(4):551-63 e556.

18. Verstreken P, Ohyama T, Haueter C, Habets RL, Lin YQ, Swan LE, Ly CV Venken KJ, De Camilli P, Bellen HJ. Tweek, an evolutionarily conserved protein, is required for synaptic vesicle recycling. Neuron. 2009;63(2):203-15.

19. Muthusamy B, Selvan LDN, Nguyen TT, Manoj J, Stawiski EW, Jaiswal BS, Wang W, Raja R, Ramprasad VL, Gupta R, et al. Next-generation sequencing reveals novel mutations in X-linked intellectual disability. OMICS. 2017;21(5): 295-303.

20. Wang K, Li M, Hakonarson H. ANNOVAR: functional annotation of genetic variants from high-throughput sequencing data. Nucleic Acids Res. 2010; 38(16):e164.

21. Auton A, Brooks LD, Durbin RM, Garrison EP, Kang HM, Korbel JO, Marchini $J \mathrm{~L}, \mathrm{McC}$ arthy S, McVean GA, Abecasis GR. A global reference for human genetic variation. Nature. 2015;526(7571):68-74.

22. Karczewski KJ, Weisburd B, Thomas B, Solomonson M, Ruderfer DM, Kavanagh D, Hamamsy T, Lek M, Samocha KE, Cummings BB, et al. The ExAC browser: displaying reference data information from over 60000 exomes. Nucleic Acids Res. 2017;45(D1):D840-5.

23. Sim NL, Kumar P, Hu J, Henikoff S, Schneider G, Ng PC. SIFT web server: predicting effects of amino acid substitutions on proteins. Nucleic Acids Res. 2012;40(Web Server issue):W452-7.

24. Adzhubei IA, Schmidt S, Peshkin L, Ramensky VE, Gerasimova A, Bork P, Kondrashov AS, Sunyaev SR. A method and server for predicting damaging missense mutations. Nat Methods. 2010;7(4):248-9.

25. Schwarz JM, Cooper DN, Schuelke M, Seelow D. MutationTaster2: mutation prediction for the deep-sequencing age. Nat Methods. 2014;11(4):361-2.

26. Kircher M, Witten DM, Jain P, O'Roak BJ, Cooper GM, Shendure J. A general framework for estimating the relative pathogenicity of human genetic variants. Nat Genet. 2014;46(3):310-5.

27. Miller DT, Adam MP, Aradhya S, Biesecker LG, Brothman AR, Carter NP, Church DM, Crolla JA, Eichler EE, Epstein CJ, et al. Consensus statement: chromosomal microarray is a first-tier clinical diagnostic test for individuals with developmental disabilities or congenital anomalies. Am J Hum Genet. 2010;86(5):749-64.

28. Stallhofer J, Denk GU, Glas J, Laubender RP, Goke B, Rust C, Brand S, Pusl T. Analysis of IL2/LL21 gene variants in cholestatic liver diseases reveals an association with primary sclerosing cholangitis. Digestion. 2011;84(1):29-35.

29. Alazami AM, Patel N, Shamseldin HE, Anazi S, Al-Dosari MS, Alzahrani F, Hijazi H, Alshammari M, Aldahmesh MA, Salih MA, et al. Accelerating novel candidate gene discovery in neurogenetic disorders via whole-exome sequencing of prescreened multiplex consanguineous families. Cell Rep. 2015;10(2):148-61.

30. Kvarnung M, Taylan F, Nilsson D, Anderlid BM, Malmgren $H$, LagerstedtRobinson K, Holmberg E, Burstedt M, Nordenskjold M, Nordgren A, et al. Genomic screening in rare disorders: new mutations and phenotypes, highlighting ALG14 as a novel cause of severe intellectual disability. Clin Genet. 2018;94(6):528-37.

31. Filatova A, Freire V, Lozier E, Konovalov F, Bessonova L, ludina E, Gnetetskaya V, Kanivets I, Korostelev S, Skoblov M. Novel KIAA1109 variants affecting splicing in a Russian family with ALKURAYA-KUCINSKAS syndrome. Clin Genet. 2019;95(3):440-1.

32. Cabet S, Putoux A, Buenerd A, Gueneau L, Reymond A, Thia EWH, Lai AHM, Schindewolf EM, Sanlaville D, Lesca G, et al. Prenatal cerebral imaging features of a new syndromic entity related to KIAA1 109 pathogenic variants mimicking tubulinopathy. Prenat Diagn. 2019;40(2):276-81.

\section{Publisher's Note}

Springer Nature remains neutral with regard to jurisdictional claims in published maps and institutional affiliations.
Ready to submit your research? Choose BMC and benefit from:

- fast, convenient online submission

- thorough peer review by experienced researchers in your field

- rapid publication on acceptance

- support for research data, including large and complex data types

- gold Open Access which fosters wider collaboration and increased citations

- maximum visibility for your research: over $100 \mathrm{M}$ website views per year

At BMC, research is always in progress.

Learn more biomedcentral.com/submissions 